\title{
Shipyard Industrial Development Studies East Kalimantan
}

\author{
WARSILAN \\ Faculty of Economics and Business, University of Mulawarman \\ email: warsilan_moch@yahoo.com
}

\begin{abstract}
Since the national policy the principle of cabotage was carried out, the development of the shipbuilding industry has not been able to keep up the growth of ocean freight industry and experiencing obstacles, because the lack of Government support both in the funding, regulation and also the construction of the infrastructure. East Kalimantan province has some of potential shipping industry in supporting the development of leading sectors. Research objectives are; identify the potential and the problem, as well as industry development strategy of formulate shipyards for Government and industry peers. Methods used through observation, interview against the perpetrators of the object of research, analyze and formulate strategy. Results of the study indicated the ship industry production costs still high, a factor restricting the price of domesticmade ships more expensive around $10 \%-30 \%$ in comparison with imported products. In addition to the production time, relatively longer because of the lack of support and other supporting components industries.
\end{abstract}

Keywords: Development, Industry, Shipyard.

\section{Introduction}

As an archipelago, Indonesia has the potential of sea transport is very large. Large ships to traditional not only a mode of transportation, but also acts as a unifying Republic of Indonesia. But until now, a decade since the national policy on cabotage principle has been implemented, the development of shipbuilding industry still has not been able to keep pace with the growth of marine transport industry. As a result, the majority of the domestic supply vessels around $60 \%$ $-70 \%$ are imported. A number of inhibiting factors, among others, the domestic price is more expensive artificial vessels between $10 \%$ to $30 \%$ compared with the imported product ships. Besides the production time is also relatively longer because of the lack of industry support components and other supporting industries (Iperindo, 2015: 53).

The shipping industry today can be less could be accelerated given the lack of government support both in terms of funding, regulation and infrastructure development. It is inevitable that Indonesia is one of the world's largest maritime countries. However, the development of shipbuilding industry in the country is still difficult to grow, because faced with various problems. Therefore, the government strongly supports growth shipbuilding industry capable of supporting the needs of sea transportation is very high.

In support of the national shipping industry, the Ministry of Industry will also increase the role of Center National Ship Design and Engineering (PDRKN) to improve ship design and engineering capabilities, increasing industrial raw materials and local components and the development of human resources skills enhancement shipbuilding center. Also, the government will provide incentives for government borne import duties (BMDTP) on raw materials that cannot be produced in the country as long as it imports the ship as a whole is not subject to import duties, while imports of raw materials are subject to import duty so that the shipbuilding industry in the country is difficult flourish, to address the need for a regulation, which is made in a balanced and mutually supportive.

Received: July 06, 2018, Revision: September 10, 2018, Accepted: December 28, 2018

Print ISSN: 0215-8175; Online ISSN: 2303-2499. DOI: http://dx.doi.org/10.29313/mimbar.v34i2.3917.464-474

Accredited B based on the decree No.040/P/2014, valid on February, 18, 2014 until February, 18, 2019. Indexed by DOAJ, Sinta, IPI 
As for the priority programs that have been implemented by the Province of East Kalimantan to support the development of maritime sector is the construction industry Kariangau Area in Balikpapan, as well as the construction of the Industrial Zone and the International Port (KIPI) Maloy in East Kutai district, is currently a Special Economic Zone Maloy. In addition, the Government of East Kalimantan and the Government Penajam Paser Utara (PPU) has also been collaborating with the Ministry of Research, Technology and Higher Education through the Agency for the Assessment and Application of Technology (BPPT) to build Indonesian Marine Science and Technology Park (IMSTEP) in Penajam Paser Utara.

Meanwhile, for the area of Samarinda and Kutai regency and Balikpapan Bay actually has long had some of the shipping industry considerable potential in terms of supporting the development of maritime sector, especially in the province of East Kalimantan. There is no doubt in the ability to build ships, several shipbuilding companies in the study area have succeeded in making a product ships that meet national and international standards. So that consumers these ships not only from within the country but also to overseas. But until now there has been no special attention from both local government district/city and East Kalimantan provincial government in supporting the development of the shipping industry.

This study aims to identify the potential for the development of shipbuilding industry and identify the factors that become an obstacle in the development of the shipbuilding industry, and determined the strategies for potential development of the shipbuilding industry in the province of East Kalimantan.

In the Maritime Word, the notion or concept of the shipyard isa place in waters with its function is to make the process of construction of the ship and repair of vessels and also to maintain (Mariti meworld.web. id/2014). Shipyard is an industrial activity that includes a process of production, namely transformation process from input of materials (steel, wood or fiberglass), widened an output which can be either the ship or offshore construction and other floating buildings. Shipbuilding industry product is finally included in Product classification oriented or Job Shops Production (Stroch, 1995). A Product oriented or Job Shops Production can often also refer to as the industry works according to orders (job order). The number or volume of production is often low and is generally used to meet specific orders and therefore a lot of variety of work to be done.

In another sense, a shipyard is also a place for building or repairing ships, so the shipyard should have; land or land and waterfront or coastline. Based on shipyard activities, it can be divided into the following (Andreasson, ER, 1980); first, new special shipyard, is special shipyard repairs and new construction and repair shipyard. The orientation of the new building is a kind of shipyard that undertake ma nufacture of new ships in accordance with the order of the owner. Secondly, the orientation of reparations is a kind of shipyard conducting ship repair maintenance work. The orientation of the new building and repair is a multifunctioning shipyard is doing new shipbuilding and maintenance/repair and modification of the vessel (Ahyari, A, 1996).

The existence of a national shipbuilding very strategic, not only in terms of business but also in terms of a role in supporting the national economy as a whole. Procurement of new ships, repair or maintenance and ship conversion is done in the country, it will save foreign exchange, absorbing huge workforce and encourage the development of supporting industries and economic sectors related (Ma'Ruf, 2007).

Shipbuilding industry today has a development which is still far from its potential, capacities, needs and efforts to promote the technology. This is illustrated by the fact that of all the shipyard in Indonesia, the production of ships issued in recent years this number is less than one percent $(1 \%)$ production of world shipbuilding (Ahmad et al., 2004).

Problems encountered in the development of shipbuilding in Indonesia is not strong shipbuilding industry as an economic sector in Indonesia (Ahmad et al., 2004) and has not been conducive investment in this field at the level of macroeconomic policy, fiscal and monetary, coordination with other relevant sectors and local governments and communities to cultivate the marine economy sector. It is closely related to industrial policy and fiscal policy in Indonesia.

The growth of the domestic shipbuilding industry is still far from expectations. In fact, the majority of which are already operating shipbuilding industry must fight 
more seriously that still exist and operate. As quoted by Dadang, (2008), published by World Shipbuilding Statistics, (Lloyd Register fair play. Ltd., June 2007), placing Indonesia as one of the shipbuilding countries of 22 countries in the world.

For that, ideally to meet a target of cabotage until last year 2014, before the enactment of cabotage in May 2011, the number of vessels operating in the country amounted to about 6 thousand new units with a capacity of 6 million gross tonnage (GT). The number of national commercial fleet until the middle of 2013 rose $132.8 \%$, to 14.064 units, with a capacity of 18.4 million GT from the previous 6.041 units in 2005, In addition, the cabotage principles also have positive impact on the increase in value of investments and the number of ships.

Fleet procurement investment in Indonesia during 2005-2014 has reached US $\$ 14$ billion ( $R p 135.28$ billion). The number is still growing because of shipping policy in the country should be served national-flagged ships (cabotage). Shipping investment will continue to grow, especially as more and more demand in the offshore sector (offshore). Moreover, $70 \%$ of oil and gas activities in the sea. By 2015 it is expected the government to enforce the cabotage principle, because it is very important for maritime countries like Indonesia. Cabotage has been in force in the United States, Japan, China, and Europe.

According to Basuki and Widjaja (2008), there are several reasons why the shipbuilding industry should be developed, among other things: the economic value of the shipbuilding industry, the development of this industry will also develop other industries that will provide a multiplier-effect significantly to the process of industrialization in the country. Besides, the shipbuilding industry is a labor-intensive industry that can create jobs is quite large with fairly high added value. With the development of this industry, the independence of the defense sector with the manufacture of defense equipment in the country will be achieved. Thus, the development program of the national shipbuilding facilities today is something that needs to be realized by the national shipbuilding industry and by the government through government-owned enterprises.

The development and expansion of business needs to be reviewed from several aspects, such as availability of raw materials, geographical conditions shipyard location, size and type of vessels to be built or repaired, the ship construction methods, human resources and production scale (Soeharto, 1996). But the most decisive fact is the technology and market production of ships and shipyard services issued it, because all it will affect productivity and business efficiency shipyard.

The shipping industry in Indonesia is still unable to compete with foreign shipbuilding industry such as Singapore, Hong Kong and Malaysia, let alone the state of competition with South Korea and Japan. From these circumstances, the need for assessment in terms of productivity and efficiency work. To support increased productivity on the construction of new vessels is necessary to develop a system that is adapted to the conditions of the shipyard. One shipyard productivity improvement effort is the ability to build ships according to the quality standards specified by the customer. Orders ship can be done on time, competitive price and adequate quality (Basuki and Choirunisa, 2012).

This is in line with research (Hasbullah, 2016) that the matter is, the operational shipyard to date is still dependent on materials/ equipment import. This means, dependence on products/components from abroad is still very dominant $(60 \%)$. The dominant factor is mostly as a primary need ship should be provided on each new ship construction (new building ship). This condition causes the shipyard with the construction of new vessels in terms of profit (profit) shipyard operations, relatively few and far greater if more work to repair / docking ship.

Productivity can be used as a measure of success of an industry or SMEs in producing goods or services. So, the higher the ratio, meaning the higher the resulting product. Measures of productivity can vary, depending on the aspects of output or input used as an aggregate basis, for example: the index of labor productivity, the productivity of the direct costs, the total cost productivity, energy productivity, the productivity of raw materials, and others.

(Herjanto 2007), Cycle productivity is one of the concepts of productivity discuss efforts to increase productivity continuously. There are four stages as the cycle of interconnected and uninterrupted i.e. the measurement, evaluation, planning and improvement. Productivity that counts only good products produced, if a work center spends a lot of defective goods can be said 
that no productive work center. The fourth of these activities has become a basic industry in conducting productivity improvement. Cycle productivity improvements used as the basis of production problems, especially on an industrial scale.

Some of the problems that led to a decrease in productivity of the company were: no evaluation of productivity, delays in decision making by management, low motivation in the work, the company is not able to compete and adapt to technological advances and information. (Gaspersz, V. 2000).

It is necessary for strategies to manage them as an explanation (Hunger \& Wheelen (1992), strategy management is a series of decisions and actions of managerial strategies that determine the performance of the company in the long term. Management strategies include environmental scanning, strategy formulation (planning strategy or long-term planning), strategy implementation, evaluation and control. Meanwhile, according to Pearce and Robinson (2008), "Strategic management is a set of decisions and actions that resulted in the formulation and execution of plans designed to achieve the company's target". The management strategy emphasizes the observation and evaluation of opportunities and threats of the environment by looking at the strengths and weaknesses of the company. Strategy is a tool used by an organization or company in order to achieve company goals and consideration of opportunities and external threats and internal strengths and weaknesses that affect the organization and the company.

In the business environment, it is divided into 2 parts, the internal environment and the external environment. The internal environment is divided into several elements: Elements of market competition (market segmentation, targeting, and positioning) and marketing mix, the External Environment is divided into 2 (two) parts, the remote environment (Politics, Economics, Social and Technology) and the industrial environment (The threat of entering new entrants, competition among companies in the industry, bargaining power of buyers, and strength of supplier bargaining).

The next approach is to use a SWOT analysis, as according Rangkuti (2009), a SWOT analysis is to identify the various factors systematically to formulate the corporate strategy. This analysis is based on the logic that maximizes the strengths and opportunities, but simultaneously can minimize your weaknesses and threats. Strategic decision-making process is always associated with the development of the mission, goals, strategies and policies of the company. Thus, strategic planning should analyze the strategic factors (strengths, weaknesses, opportunities, and threats) in the conditions that exist today, it is called a Situation Analysis. The most popular models for the analysis of the situation is the SWOT analysis.

Associated with all internal and external problems experienced by the national shipbuilding industry comes down to productivity and competitiveness is low, so that the necessary solutions that are comprehensive and strategic. Yardstrat model application on the national shipbuilding strategy demonstrates the need for application-intensive and integrative strategies to create a sustainable competitive edge. However, for the effectiveness of its implementation, it is also necessary to make industry reinforcement and harmonization of policies to encourage the production of ships in the country, among others: control of the domestic market, the standardization of the type and size of the domestic ship, the revitalization of shipyard and application of advanced technology, capacity building and clusters shipyard, funding patterns, and development of local components industry. (Ma'Ruf, 2014: 23).

\section{Research Method}

This study was included in the exploratory because of research done to find the cause or things that influence the occurrence of something. Similarly, this study included descriptive research, because it's made some descriptive explanation of the variables studied. In his explanation, (Sugiyono, 2012: 119), that the population is generalization region of an object/subject specified in the study. While the sample is a portion of that population. Thus, the population nature of this research is the shipbuilding industry group of large, medium and small scattered in the area of East Kalimantan Province. Shipbuilding in d ustry many large / medium and small based on statistical data, 2017. In Table 1.

The determination of the sample size (Gay (1976) in (Sedarmayanti and 
Hidayat, 2002: 144-145), states that the minimum sample size that can be used for a descriptive study, at least $10 \%$ of the population, if the population is small at least $20 \%$. In this study due to the variation of the population in each location for large groups and medium industry only 8 units, then conducted a census to 8 respondents. While a small group industry (SME) for each location of $10 \%$ of the population; As many as 11 respondents Samarinda, Kutai 2 respondents and Balikpapan 3 respondents. The number of small industrial sample as many as 16 respondents. The amount of the overall sample of 24 respondents, after the deployment of questionnaire filled and returned from 20 respondents.

Table 1

Number of Shipbuilding Industry By Industry Group

\begin{tabular}{lllll}
\hline $\begin{array}{l}\text { Industry } \\
\text { group }\end{array}$ & Samarinda & Kukar & $\begin{array}{l}\text { Balik- } \\
\text { papan }\end{array}$ & $\begin{array}{l}\text { to- } \\
\text { tal }\end{array}$ \\
\hline $\begin{array}{l}\text { Large / } \\
\text { medium }\end{array}$ & 5 & 1 & 2 & 8 \\
\begin{tabular}{l} 
Small \\
\hline
\end{tabular} & 114 & 19 & 32 & 170 \\
\hline
\end{tabular}

Source: BPS -Direktori Medium and Large Industrial Company of East Kalimantan Province in 2017

Data collection techniques in this study performed with interview (interview), questionnaires (questionnaire), observation and documentation. The type of data obtained in the form of primary data and secondary data. From primary and secondary data are tabulated, analyzed descriptively, qualitatively and quantitatively in the form of tables and diagrams are easy to understand.

Data analysis and processing method used is the analysis of policy approaches Strength, Weakness, Opportunities, and Threat (SWOT). SWOT method is used to determine the evaluation of development by analyzing the internal and external factors affecting the shipbuilding industry.

\section{Research result}

Based on the results of the deployment of a list of questions submitted to the respondents as businesses shipbuilding industry in the study area was selected, then the responses obtained in the form of perception related to the potential development of shipbuilding industry both industry groups small, medium and large can be described as follows:

\section{Availability of Raw Materials}

The results of respondents' answers ease and availability of raw materials as inputs in the production process in Table 2.

Table 2

Respondents Against Raw Material Availability

\begin{tabular}{|c|c|c|c|c|}
\hline No. & Category & Scale & Frequency & Percentage \\
\hline 1 & Well & $7-9$ & 16 & 80 \\
\hline 2 & moderate & $4-6$ & 4 & 20 \\
\hline \multirow[t]{3}{*}{3} & Bad & $1-3$ & - & - \\
\hline & TOTAL & & 20 & 100 \\
\hline & Average va & alue & 6.66 & \\
\hline
\end{tabular}

In Table 2 as much as 16 respondents or $80 \%$ answered that the availability of raw materials in both categories. There are as many as 4 respondents or $20 \%$ answered that the availability of raw materials in the medium category. Indicated that the availability of raw materials for the production needs of shipyards in East Kalimantan province region can be obtained easily and reasonably available.

\section{Support Banking}

The results of the answers of respondents to support the banking sector in the shipbuilding industry in table 3 .

\section{Table 3}

Respondents Against Banking Support

\begin{tabular}{|c|c|c|c|c|}
\hline No. & Category & Scale & Frequency & Percentage \\
\hline 1 & Well & $7-9$ & 11 & 55 \\
\hline 2 & moderate & $4-6$ & 7 & 35 \\
\hline \multirow[t]{3}{*}{3} & Bad & $1-3$ & 2 & 10 \\
\hline & TOTAL & & 20 & 100 \\
\hline & Average $\mathrm{v}$ & alue & 5.7 & \\
\hline
\end{tabular}

Source: Appendix Table 2.

In Table 3, that there are as many as 11 respondents or $55 \%$ answered that the support of banks in supporting the capitalization of work in the shipbuilding industry is in both categories. A total of seven respondents or $35 \%$ answered that the support of banks in the medium category. A total of 2 respondents or $10 \%$ answered that the support of banks in the bad category. It is indicated that the support of the banks to support the capitalization of work in the area 
of shipbuilding industry in East Kalimantan province is still not equitable for shipbuilding industry.

\section{Human Resource Capability}

The results of respondents' answers to the human resource capacity of the company to an industrial production process shipyard in Table 4.

Table 4

Respondents Against The ability of the human resources

\begin{tabular}{lllll}
\hline No. & Category & Scale & Frequency & Percentage \\
\hline 1 & Well & $7-9$ & 17 & 85 \\
2 & moderate & $4-6$ & 3 & 15 \\
3 & Bad & $1-3$ & - & - \\
\hline & TOTAL & $\mathbf{2 0}$ & 100 \\
& Average value & 6,63 & \\
\hline
\end{tabular}

Source: Appendix Table 2.

In Table 4 as much as 17 respondents or $85 \%$ answered that the ability of the human resources to support the productivity of shipyards in both categories. There are as many as 3 respondents or $15 \%$ answered that the human resource capacity in the medium category. Indicated, the ability of the human resources to support the productivity of the shipbuilding industry in the Province of East Kalimantan in general capable and competent in their fields.

\section{Production Process Capability(R\&D)}

The results of respondents' answers to the ability of the production process (R \& $D$ ) of the company for the production process of the shipbuilding industry in Table 5.

Table 5

Respondents Against Production Process Capability (R \& D)

\begin{tabular}{|c|c|c|c|c|}
\hline No. & Category & Scale & Frequency & Percentage \\
\hline 1 & Well & $7-9$ & 19 & 95 \\
\hline 2 & moderate & $4-6$ & 1 & 5 \\
\hline 3 & Bad & $1-3$ & - & - \\
\hline & \multicolumn{2}{|l|}{ TOTAL } & 20 & 100 \\
\hline & \multicolumn{2}{|c|}{ Average value } & 7.06 & \\
\hline
\end{tabular}

In Table 5, as many as 19 respondents or $95 \%$ answered that the ability of the production process $(R \& D)$ in the construction of ships in both categories. There are only
1 or equal to $5 \%$ of respondents said that the ability of the production process ( $R$ \& $D$ ) category is. Indicated production process capability ( $R \& D$ ) in the manufacture or construction of ships for

the shipbuilding industry in the region East Kalimantan province have capable to meet production standards-based ( $\&$ \&).

\section{Ability Meet Product Quality Stan- dards}

The results of respondents' answers to the ability to meet the Standards of Quality Products by the company's shipbuilding industry is presented in Table 6.

Table 6

Respondents Against Product Quality Standards

\begin{tabular}{|c|c|c|c|c|}
\hline No. & Category & Scale & Frequency & Percentage \\
\hline 1 & Well & $7-9$ & 18 & 90 \\
\hline 2 & moderate & $4-6$ & 2 & 10 \\
\hline \multirow[t]{3}{*}{3} & Bad & $1-3$ & - & - \\
\hline & TOTAL & & 20 & 100 \\
\hline & Average $\mathrm{v}$ & alue & 6.83 & \\
\hline
\end{tabular}

In Table 6 as many as 18 respondents or $90 \%$ answered that the quality standards of products in shipbuilding in both categories. There are as many as 2 respondents or $10 \%$ answered that the quality standards of products in shipbuilding in the medium category. Indicated that the product quality standards in shipbuilding for the shipbuilding industry in the province of East Kalimantan in either category, quality and product quality has met the standards desired by consumers.

\section{Prospective Domestic Market}

Results of a prospective respondents to the domestic market by the company's shipbuilding industry in Table 7.

Table 7

Respondents Against Domestic Market

\begin{tabular}{lllll}
\hline No. & Category & Scale & Frequency & Percentage \\
\hline 1 & Well & $7-9$ & 13 & 65 \\
2 & moderate & $4-6$ & 7 & 35 \\
3 & Bad & $1-3$ & - & - \\
\cline { 1 - 3 } & TOTAL & 20 & 100 \\
\cline { 2 - 3 } & \multicolumn{2}{l}{ Average value } & 5.53 & \\
\hline
\end{tabular}

Source: Appendix Table 2. 
In Table 7 as many as 13 respondents or $65 \%$ answered that prospective domestic market for the needs of the vessel is included in both categories. There are as many as seven respondents or $35 \%$ answered that prospective domestic market for the needs of the vessel is included into the category of being. Indicated that prospective domestic market for the needs of ships supplied by the shipbuilding industry in the area of East Kalimantan province with huge potential market share.

\section{Promotional Products By Industry and Government}

The results of respondents' answers to the Promotional Products made by industry and government on the results of the shipbuilding industry in Table 8.

Table 8

Respondents Against Product Promotion by Government

\begin{tabular}{lllll}
\hline No. & Category & Scale & Frequency & Percentage \\
\hline 1 & Well & $7-9$ & 6 & 30 \\
2 & moderate & $4-6$ & 12 & 60 \\
3 & Bad & $1-3$ & 2 & 10 \\
\hline \multicolumn{3}{l}{ TOTAL } & 20 & 100 \\
\cline { 2 - 3 } & Average value & 5.4 & \\
\hline \multicolumn{3}{l}{} \\
\hline
\end{tabular}

In Table 8 by 6 respondents or 30\% answered that the campaign carried out by the industry and government in both categories. While as many as 12 respondents or $60 \%$ answered that the campaign carried out by the industry and government in the medium category. While 2 respondents or $10 \%$ answered that the campaign carried out by the industry and government in the bad category. Indicated that the promotion of products of the vessel conducted by the industry and government in the area of shipbuilding industry in East Kalimantan province is still lacking.

\section{Role of Industry Associations}

The results of respondents' answers to the role of industry associations ship in businesses or industry association members shipyard in Table 9.

In table 9 of 16 respondents or $80 \%$ answered that the role of industry associations in supporting the development of shipbuilding in both categories. A total of 3 respondents or $15 \%$ answered that the role of industry associations in the medium category. There are only 1 or equal to $5 \%$ of respondents answered that the role of industry associations in the bad category. Indicated that the role of industry associations in supporting the development of shipbuilding industry in the area of East Kalimantan province has been instrumental in the development of shipbuilding industry potential.

\section{Table 9}

\section{RespondentsAgainst Role of Industry} Associations

\begin{tabular}{lllll}
\hline No. & Category & Scale & Frequency & Percentage \\
\hline 1 & Well & $7-9$ & 16 & 80 \\
2 & moderate & $4-6$ & 3 & 15 \\
3 & Bad & $1-3$ & 1 & 5 \\
\hline \multicolumn{3}{l}{ TOTAL } & 20 & 100 \\
\cline { 2 - 3 } & Average value & 5.63 & \\
\hline \multicolumn{5}{r}{ Source: Appendix Table 2 }
\end{tabular}

\section{Central Government and Regional Policy}

The results of respondents' answers to the central government's policy towards the national shipbuilding industry in Table 10.

At table 10, as many as 9 respondents or $45 \%$ answered that the policy of the central government in implementing regulations for the shipbuilding industry is included in both categories. A total of 9 respondents or $45 \%$ answered that the policy of the central government in implementing regulations for the shipbuilding industry in the medium

Table 10

Respondents Against Central Government Policy

\begin{tabular}{ccccc}
\hline No. & Category & Scale & Frequency & Percentage \\
\hline 1 & Well & $7-9$ & 9 & 45 \\
2 & moderate & $4-6$ & 9 & 45 \\
3 & Bad & $1-3$ & 2 & 10 \\
\hline \multicolumn{2}{c}{ TOTAL } & 20 & 100 \\
\cline { 2 - 5 } & \multicolumn{2}{c}{ Average value } & 5.23 & \\
\hline
\end{tabular}


category. There are 2 respondents or $10 \%$ answered that the policy of the central government in applying the regulation in the bad category. Indicated that the policy of the central government in implementing regulations are still not able to lift the perceived potential development of shipbuilding industry over the years.

Table 11

Matriks SWOT Analysis Shipbuilding Small Industry Shipyard

\begin{tabular}{|c|c|c|}
\hline IFAS & $\begin{array}{l}\text { Strength (S) } \\
\text { - } \quad \text { The ease and availability of } \\
\text { Raw Materials } \\
\text { - } \quad \text { The ability of its human } \\
\text { resources industry } \\
\text { - } \quad \text { utilization Technology } \\
\text { - } \quad \text { Production Process } \\
\text { Capability (R \& D) } \\
\text { - } \quad \text { The production facilities } \\
\text { (manufacturing) } \\
\text { - Conformity of Production } \\
\text { Capacity and turnaround } \\
\text { times } \\
\text { - Production Systems } \\
\text { (booking and not booking) } \\
\text { - Standard Product Quality } \\
\text { - The cost efficiency of } \\
\text { production } \\
\text { - Production costs } \\
\text { competitiveness in the } \\
\text { market } \\
\text { The market share covered } \\
\text { local, regional, national } \\
\text { Management (Structure } \\
\text { Perush., Organizational } \\
\text { Culture and resource } \\
\text { companies) }\end{array}$ & $\begin{array}{ll}\text { Weakness (W) } \\
\text { - } & \text { Financial support, obtaining } \\
& \text { capital and expansion of } \\
& \text { investment from financial } \\
& \text { institutions } \\
\text { - } & \text { Information Systems } \\
\text { - } & \text { Continuity Market and } \\
& \text { customers } \\
\text { - } & \text { Promotional Products by } \\
& \text { industry and government } \\
\text { - } & \text { The role of the Association }\end{array}$ \\
\hline $\begin{array}{l}\text { OPPORTUNITIES (O) } \\
-\quad \text { Fulfillment of input factors } \\
\text { (material) by suppliers } \\
\text { - } \quad \text { The existence of industrial } \\
\text { clusters } \\
\text { - Increased government } \\
\text { regulation } \\
\text { - } \quad \text { The emergence of new } \\
\text { technologies } \\
\text { - Environmental Factors Political } \\
\text { towards the shipbuilding } \\
\text { industry } \\
\text { - Ecological factors of the } \\
\text { shipbuilding industry }\end{array}$ & $\begin{array}{l}\text { SO strategy } \\
\text { - } \quad \text { Human resource } \\
\text { development, and improve } \\
\text { the use of new technologies } \\
\text { - Improving product quality, } \\
\text { - } \quad \text { Meet the standard } \\
\text { classification of Ships } \\
\text { - Adjustment and anticipation } \\
\text { to changes in the business } \\
\text { environment factors }\end{array}$ & 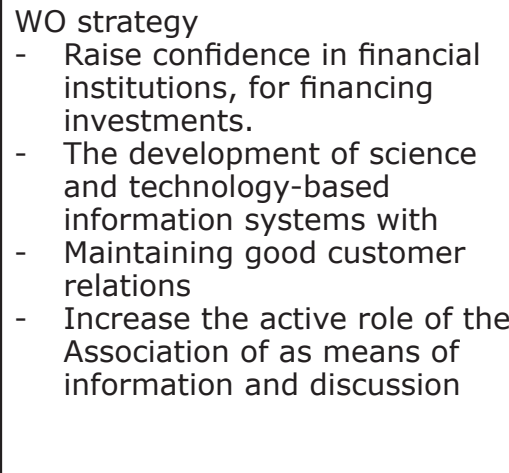 \\
\hline $\begin{array}{ll}\text { THREATS (T) } \\
-\quad \text { prospective market } \\
-\quad \text { Community / Shipbuilding } \\
\text { - } \quad \text { Cendustry Group } \\
-\quad \text { Local Government Policy } \\
-\quad \text { Role of Financial Institutions } \\
-\quad \text { Increased competition } \\
-\quad \text { Of particular interest group } \\
-\quad \text { Climate conditions of the } \\
\quad \text { national economy on the } \\
\text { shipbuilding industry } \\
\text { Climate conditions of the } \\
\quad \text { global economy on the } \\
\text { shipbuilding industry } \\
\text { - Social environmental factors } \\
\text { on the shipbuilding industry }\end{array}$ & $\begin{array}{l}\text { ST strategy } \\
\text { - } \quad \text { Increase market share } \\
\text { - } \quad \text { development promotion } \\
\text { - } \quad \text { Improving product quality } \\
\text { standards in order to cope } \\
\text { with increasing competition } \\
\text { - } \quad \text { Adjustment of the } \\
\text { production system } \\
\text { according to anticipate the } \\
\text { market share of national } \\
\text { economic climate and the } \\
\text { global economy }\end{array}$ & $\begin{array}{l}\text { WT strategy } \\
\text { - Mapping products in } \\
\text { accordance with shipbuilding } \\
\text { capability regulated by } \\
\text { government policies } \\
\text { - Through the association } \\
\text { created the role of } \\
\text { information systems to } \\
\text { determine the prospective } \\
\text { market update }\end{array}$ \\
\hline
\end{tabular}


Table 12

Matrix SWOT Analysis Shipbuilding Large/Medium Industry

\begin{tabular}{|c|c|c|}
\hline EFAS & 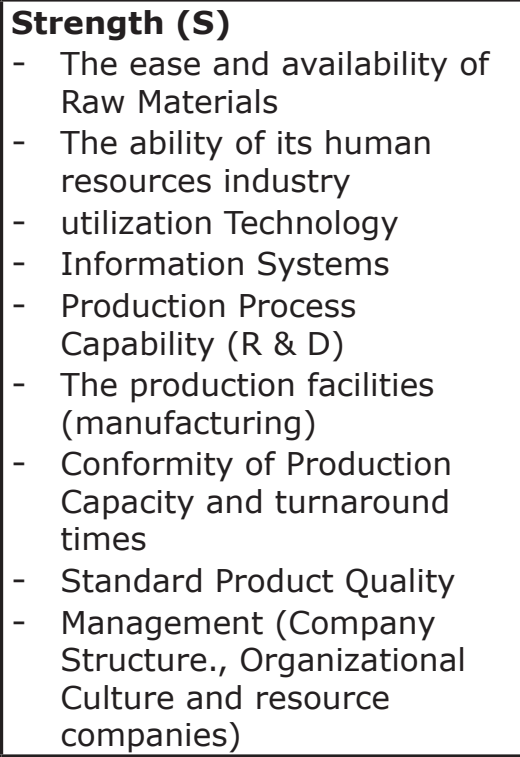 & 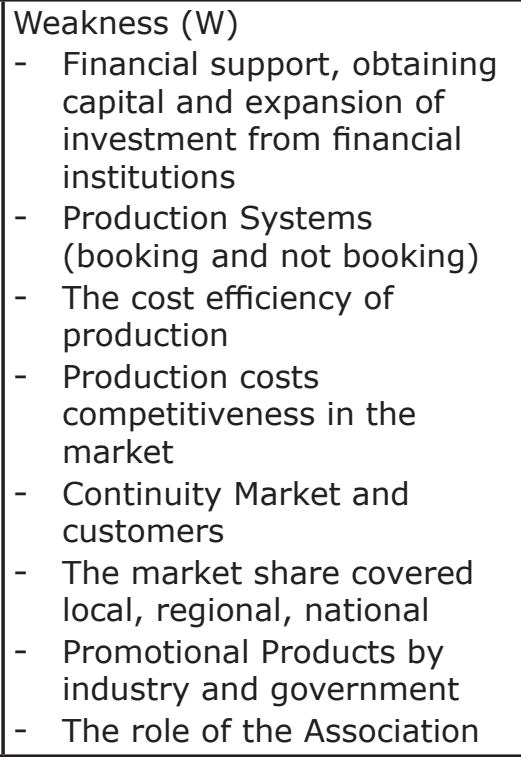 \\
\hline $\begin{array}{ll}\text { OPPORTUNITIES (O) } \\
\text { - } & \text { prospective market } \\
\text { - } & \text { Community / Shipbuilding } \\
& \text { Industry Group } \\
\text { - } & \text { Fulfillment of input factors } \\
& \text { (material) by suppliers } \\
\text { - } & \text { The existence of industrial } \\
& \text { clusters } \\
\text { - } & \text { Central Government Policy } \\
\text { - } & \text { Local Government Policy } \\
\text { - } & \text { Increased government } \\
& \text { regulation } \\
- & \text { Role of Financial Institutions } \\
- & \text { Role of Financial Institutions } \\
- & \text { Increased competition }\end{array}$ & 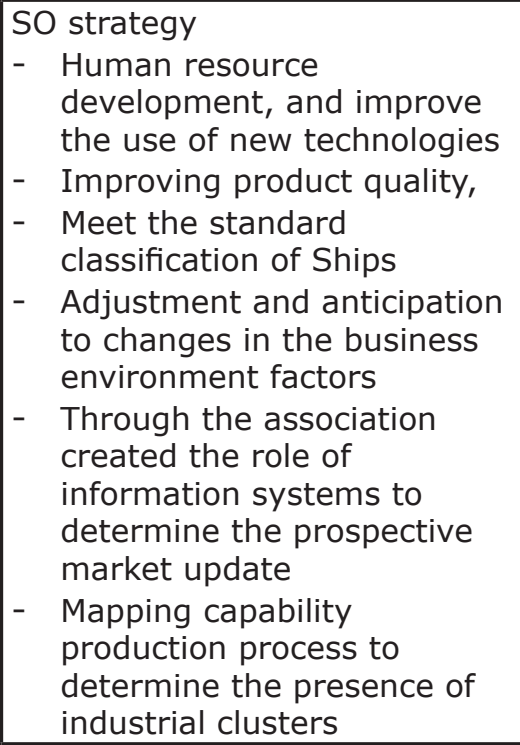 & 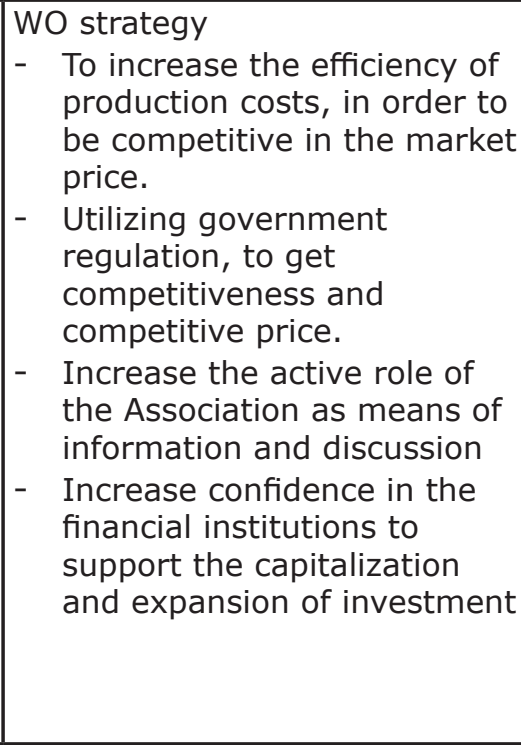 \\
\hline $\begin{array}{l}\text { THREATS (T) } \\
\text { - } \quad \text { Of particular interest group } \\
\text { - } \quad \text { Climate conditions of the } \\
\text { national economy on the } \\
\text { shipbuilding industry } \\
\text { - } \quad \text { Climate conditions of the } \\
\text { global economy on the } \\
\text { shipbuilding industry } \\
\text { - } \quad \text { Environmental Factors } \\
\text { Political towards the } \\
\text { shipbuilding industry }\end{array}$ & $\begin{array}{l}\text { ST strategy } \\
\text { - } \quad \text { Optimizing the management } \\
\text { system that balanced } \\
\text { between construction and } \\
\text { maintenance of the ship } \\
\text { in order to anticipate the } \\
\text { economic climate, national } \\
\text { and global economy }\end{array}$ & $\begin{array}{l}\text { WT strategy } \\
\text {-Adjustment of the system of } \\
\text { production and anticipation } \\
\text { of changes in the political } \\
\text { and business environment } \\
\text { factors } \\
\text {-Utilizing market share of } \\
\text { local, regional, and national } \\
\text { levels to address the } \\
\text { national economic climate } \\
\text { conditions and the global } \\
\text { economy }\end{array}$ \\
\hline
\end{tabular}

Source; Table Appendix.

\section{SWOT analysis}

The results of descriptive analysis by matrix analysis of internal and external factors through SWOT approach to the shipbuilding industry both large, medium and small in the region, this time need to needs of implementation and alternatives strategies that can be combined with each other based on the conditions and resource capability company. Three first strategy is a type of intensive strategies wholly within the 
control of management, such as concentric diversification strategy. Other strategies classified types of strategies that are relatively difficult, it takes time and has important implications, as it involves related parties outside the company. Form of implementation of each of these strategies are market penetration strategies, market development strategy, product development strategy,

Based on the results of the previous analysis, that the shipping industry business conditions in the study area can be identified as some things that describe the current conditions are: (1) Availability of raw materials for the production needs can still be obtained easily and readily available; (2) Support from the banks to support the capitalization of work is still not evenly distributed; (3) The ability of the human resources to support the productivity of production in general is still capable and competent in the field; (4) The ability of the production process ( $R \& D$ ) in the manufacture or construction of ships have been able and meet the production standards-based (R \& D); (5) Standard quality products in shipbuilding either category, in terms of quality and product quality, has met the standards desired by consumers; (6) Prospective domestic market for the required vessel belongs to market share potential. (7) Promotional products ship made by industry and government in the area of shipbuilding industry in East Kalimantan province is still not optimal; (8) The role of the association in supporting the development of shipbuilding industry in the study area is needed; (9) The central government in implementing national rules or regulations for the shipbuilding industry and they have yet to lift the potential development of shipbuilding industry in the province of East Kalimantan; (10) The policy of local government in applying the rules or regulations to encourage the development of shipbuilding industry in the area of East Kalimantan province is still not optimal. (9) The central government in implementing national rules or regulations for the shipbuilding industry and they have yet to lift the potential development of shipbuilding industry in the province of East Kalimantan; (10) The policy of local government in applying the rules or regulations to encourage the development of shipbuilding industry in the area of East Kalimantan province is still not optimal. (9) The central government in implementing national rules or regulations for the shipbuilding industry and they have yet to lift the potential development of shipbuilding industry in the province of East Kalimantan; (10) The policy of local government in applying the rules or regulations to encourage the development of shipbuilding industry in the area of East Kalimantan province is still not optimal.

\section{Conclusion}

Based on the analysis and discussion of industrial development studies shipyards in East Kalimantan province is generally sufficient potential to support the development of the maritime sector. But do not have strong competitiveness in comparison with the production of ships from other countries such as China, the Philippines, and Vietnam, because of the high cost of production. The other obstacle factor is the price of domesticmade ships more expensive approximately $10 \%$ - 30\% compared with the imported product ships. Besides time, production is also relatively longer because of the lack of industry support components and other supporting industries. The study recommended that the central and regional governments as well as perpetrators of shipbuilding industry in the region of East Kalimantan Province, to improve the competitiveness of the domestic shipbuilding industry through intensive strategies (in particular the market penetration strategies and market development) and integrative strategies (in particular the integration strategy of horizontal and backward integration strategy with suppliers of basic materials).

To deal with the climatic conditions of the national economy and the global economy at present, the necessary strategy of developing the potential of shipbuilding industry through the development of human resources, improvement of product quality, the standard of quality products and the most important thing is adaptation and anticipation of changes in business environment factors of uncertainty over the development of the field repair or maintenance of the ship (Docking repair \& maintenance).

Similarly, the importance of the government's attention needs to deregulation rules to promote the smooth operation of the shipyard in order to be competitive with the product ships from other countries.

\section{References}

-----,(2005). Instruksi Presiden Nomor 
5 Tahun 2005 tentang Pemberdayaan Industri Pelayaran Nasional

-----,(2008).Undang-Undang Republik Indonesia Nomor 17 Tahun 2008, Tentang Pelayaran.

-.-.--, (2012).Transmedia, Majalah Kementerian Perhubungan. Edisi 11, Kementerian Perhubungan RI. Jakarta. ,(2008). Kajian Ekonomi Regional Provinsi Kepulauan Riau Triwulan I-2008

Andreasson, ER (1980), Managing Ship Production, Coures Notes, University of Strathclyde, Glasgow.

Ahyari, A, (1996). Manajemen Produksi Perencanaan Sistem Produksi, Balai Penerbit Fakultas Ekonomi (BPFE), Yokyakarta, edisi IV.

Ahmad, M., Nofrizal dan Jasmoro (2004). Manajemen galangan kapal perikanan skala menengah di Dumai. Jurnal IImu Administrasi Publik and Bisnis 2 (2): 120 $-128$

BPS, (2017). Direktori: Perusahaan Industri Besar dan Sedang, Provinsi Kalimantan Timur 2017.

Basuki, M. dan Choirunisa, B, (2012).Analisa Risiko Proses Pembangunan Kapal Baru 3.500 LTDW White Product Oil Tanker Pertamina di PT. Dumas Tanjung Perak Surabaya, Jurnal Neptunus, Volume 18, Nomor 2, pp. 97-109, Edisi Juli 2012, Fakultas Teknik UHT.

Basuki, M dan Widjaja, S, 2008. Studi Pengembangan Model Manajemen Risiko Usaha Bangunan Baru Pada Industri Galangan Kapal, Prosiding Seminar Nasional Teknologi Produksi, Jurusan Teknik Perkapalan, FTMK ITATS.

Dadang,(2008). Menuju Era Emas Industri Perkapalan Nasional, diunduh dari https: //www.its.ac.id/ news/2008/03/13/ menuju-era-emas-industri-perkapalannasional/

Herjanto Eddy, (2007). Manajemen Operasi, edisi ketiga, Jakarta: PT.Grasindo

Gaspersz, V. (2000). Manajemen Produktivitas Total. PT Gramedia Pustaka Utama.
Jakarta

Hasbullah Mansyur,(2016). Strategi Penguatan Galangan Kapal Nasional dalam Rangka memperkuat Efektifitas dan Efisiensi Armada Pelayaran Domestik Nasional 2030. Jurnal Riset dan Teknologi Kelautan (JRTK).Volume 14, Nomor 1, Januari - Juni 2016: $p p-103-112$

http://www. maritimeworld.web.id/2014/05/ galangan-kapal-atau-dock-kapalshipyard.html

Iperindo, (2015). Direktori IPERINDO 20152016, Ikatan Perusahaan Industri Kapal dan Sarana lepas Pantai Indonesia, Jakarta.

Ma'ruf,B., Okumoto,Y. and Widjaja,S. (2006).Environmental-Based Strategic Management Model for Indonesian's Medium-Sized Shipyard. Journal of Ship Production, Vol.22, No. 4, November 2006, pp. 195-202.

Ma'ruf, B., 2014.Strategi Pengembangan Industri Kapal Nasional Berbasis Teknologi Produksi dan Pasar Domestik. Orasi Pengukuhan Profesor Riset Bidang Teknik Maritim, Badan Pengkajian Dan Penerapan Teknologi Jakarta, 17 Oktober 2014.

Rangkuti, Freddy, (2009).Analisis SWOT Teknik Membedah Kasus Bisnis. Edisi Keenam Belas, PT. Gramedia Pustaka Utama, Jakarta.

Soeharto,A, dan Soejitno, (1996). Galangan Kapal. Fakultas Teknik Kelautan- ITS. Surabaya

Sugiyono, (2012). Metode Penelitian Kombinasi, Penerbit Alfabeta, Bandung.

Sedarmayanti dan Syarifudin,H.,(2002). Metodologi Penelitian, Penerbit Mandar Maju, Bandung.

Wheelen, Thomas L. , J. David Hunger. (1992). Strategic Management and business Policy. Edisi Keempat. USA: Addison-Wesley Publishing Company,Inc.

Pearce II, John A. dan Robinson Richard B.Jr. (2008). Manajemen Strategis Ed.10. Salemba Empat: 